\title{
Nano Iron Oxide Impregnated Poly(Vinylidene Fluoride) Ultrafiltration Membrane for Palm Oil Mill Effluent Treatment
}

\author{
Chia Siang Ooi, ${ }^{1 *}$ Mieow Kee Chan, \\ ${ }^{I}$ Centre for Water Research, Faculty of Engineering and the Built \\ Environment, SEGi University. \\ *mkchan@segi.edu.my
}

\begin{abstract}
Palm oil mill effluent (POME) is highly organic loaded liquid waste in the palm oil industry. Membrane technology is preferred as the tertiary treatment due to the high removal efficiency and low space requirement. However, membrane fouling is the drawback of membrane technology, which increases the operational cost. Thus, the objective of this research is to improve the anti-fouling property of poly(vinylidene-fluoride) (PVDF) membrane by using nano $-\mathrm{Fe}_{3} \mathrm{O}_{4}$ as the additive. $\mathrm{Nano}-\mathrm{Fe}_{3} \mathrm{O}_{4}$ was synthesized through chemical reduction method, and it was proved by the Energy Dispersive X-ray spectroscopy (EDX) spectrum. The nano iron oxide was added to the Poly(vinylidene-fluoride)/ Polyvinylpyrrolidone solution and cast into membranes. The hydrophilicity of nano $-\mathrm{Fe}_{3} \mathrm{O}_{4}$ modified the membrane surface and improved the antifouling property. This was proved by the lower contact angle of $\mathrm{PVDF} /$ nano $-\mathrm{Fe}_{3} \mathrm{O}_{4}$ membranes $\left(70.99^{\circ}\right)$ compared to the neat membrane $\left(77.13^{\circ}\right)$. PVDF/ nano $-\mathrm{Fe}_{3} \mathrm{O}_{4}$ membranes exhibited better separation performance compared to the neat membrane, especially in BOD removal. PVDF/nano iron oxide membrane removed $94.73 \%$ of BOD while $88.67 \%$ BOD was removed by the neat membrane. At the same time, the membranes exhibited consistent COD and TSS removal in the first 5 cycles in treating POME. A slight reduction in BOD removal was observed from the first cycle to the fifth cycle suggested the use of other membrane cleaning method is required to remove the foulants. In conclusion, nano - $\mathrm{Fe}_{3} \mathrm{O}_{4}$ improved the anti-fouling property of PVDF membrane, and a comprehensive
\end{abstract}


study on membrane cleaning shall be conducted in the near future for sustainable use.

Keywords: Palm oil mill effluent; Poly(vinylidene-fluoride); Iron oxide nanoparticles; Antifouling property, BOD

\section{Introduction}

Oil palm (Elaeis guineensis) is a versatile crop, and its growth is limited to tropical areas such as Malaysia and Indonesia (Ahmad et al., 2018). Malaysia as the second-largest producer of palm oil in the world produced 17.73 million tonnes crude palm oil (CPO) in the year of 2008 (MPOB, 2008) and increased to 19.52 million tonnes in 2018 (MPOB, 2018). Despite the significant economic benefit earned from oil palm production, it causes serious environmental problem as a large volume of polluted wastewater is generated during the extraction and refining processes (Azmi and Yunos, 2014; Bello and Abdul Raman, 2017). Palm oil mill effluent (POME) is a brown non-toxic thick liquid waste with an unpleasant odour (Yacob et al., 2006). 75 million tonnes of POME were produced from the palm oil mills in Malaysia in 2016 (Dalton et al., 2017). The raw POME contains high polluting compounds such as $25000 \mathrm{mg} / \mathrm{L}$ biological oxygen demand (BOD), $51000 \mathrm{mg} / \mathrm{L}$ chemical oxygen demand (COD) and $18000 \mathrm{mg} / \mathrm{L}$ suspended solid (SS) that cause severe impact to the environment (MPOB, 2014). Untreated POME lowers the quality of water for domestic use (Ezemonye et al., 2008; Izah et al., 2016), causes eutrophication which leadss to the depletion of oxygen (Awotoye et al., 2011) and endangers the aquatic life.

Conventional ponding system is a well-known method for POME treatment in Malaysia as this method is cost-effective and simple. However, long hydraulic retention time and the need for a large land area are the main drawbacks of this treatment. Thus, other methods such as coagulation and flocculation, advanced oxidation process, microalgae cultivation and membrane treatment are proposed. Among these methods, membrane separation shows excellent chemical oxygen demand (COD) and total 
suspended solid (TSS) removal within a short treatment time. It produces effluent with stable and consistent quality. Therefore, membrane technology is introduced as the secondary treatment to treat POME up to the allowable discharge limit (Ghani et al., 2018).

Ultrafiltration membrane is ideal for POME treatment due to its moderate pore size. Studies showed that the UF membrane-treated POME could be reused by recycling the treated water to the palm oil mill (Azmi and Yunos, 2014; Ghani et al., 2018). However, membrane fouling is the main problem found in the separation process. It reduces the separation performance, reduces permeate flux as well as reduces the life span of the membrane (Ghani et al., 2018). Thus, it increases the cost of treatment.

Findings from the research works showed that the low hydrophilicity of membrane contributed to the fouling phenomena (Kumar and Ismail, 2015). Modification of membrane such as blending with inorganic nanoparticle enhances its hydrophilicity and exhibits antifouling property (Benavente et al., 2017; Pereira et al., 2018). Thus, the objective of this study is to investigate the performance of nano- $\mathrm{Fe}_{3} \mathrm{O}_{4}$ in improving the antifouling property of hydrophobic polyvinylidene fluoride (PVDF) membrane. PVDF resists to acidic condition, which made it an ideal material to treat acidic POME. Besides, it also exhibits excellent mechanical strength, resists to high temperature, and cost-effective (Lalia et al., 2013; He et al., 2014).

\section{Materials and methods}

2.1.Materials

PVDF $(\mathrm{Mw}=\sim 534,000)$ was purchased from Sigma-Aldrich and used as the membrane-forming material. Polyvinylpyrrolidone K30 (PVP, K30) was supplied by Vchem Laboratory Chemicals as the pore-forming agent while $\mathrm{N}$, N-Dimethylformamide (DMF $>99.8 \%$ ) was used as the solvent. Biologicaltreated POME was obtained from a local mill factory at the extended aerobic ponding (Teluk Intan, Perak). POME was stored at $4{ }^{\circ} \mathrm{C}$ to avoid microbial decomposition (Aziz and Hanafiah, 2017b). Iron (II) sulfate heptahydrate, sodium carbonate were obtained from Merck Germany. Ethanol with 99\% 
purity and ethylenediaminetetraacetic acid (EDTA) with 0.1 Molarity was supplied by Fisher Scientific. All the chemicals were used as received.

\subsection{Preparation of iron oxide nanoparticles}

$0.1 \mathrm{M}$ of iron (II) sulfate heptahydrate and $0.05 \mathrm{M}$ of EDTA were mixed by using the overhead stirrer at $300 \mathrm{rpm}$. Iron in the solution was reduced by adding $0.75 \mathrm{M}$ of sodium carbonate dropwise to the mixture. The black precipitate (iron oxide) was further reduced by immersing in $1.0 \mathrm{M}$ of sodium carbonate. The iron oxide nanoparticle was rinsed three times using ethanol and stored in ethanol (Guo et al., 2018; Zin et al., 2013) before use.

\subsection{Membrane fabrication and characterization}

The polymer solution was prepared according to the formula in Table 1. An appropriate amount of iron oxide nanoparticle was dispersed in DMF using ultrasonic vibrator for 1 hour. Then, $19 w t \%$ of PVDF and $3 w t \%$ of PVP were added into the DMF solution and stirred at $400 \mathrm{rpm}$ for 4 hours at $85^{\circ} \mathrm{C}$. The polymer solution was degassed at room temperature (Homayoonfal et al., 2010; Ong et al., 2014). The bubble-free solution was cast by using the semiautomated casting machine (Chan and Teo, 2013). The blade of the semiautomated casting machine was adjusted to $200 \mu \mathrm{m}$ from the surface of the glass plate using the digital micrometer, and the polymer solution was cast at $7 \mathrm{~cm} / \mathrm{s}$ (Chan et al., 2016). The casted film was immediately placed into the oven for 9 minutes at $60^{\circ} \mathrm{C}$ before placed into RO water. The membrane was then rinsed with $\mathrm{RO}$ water to remove the remaining solvent. Lastly, the membrane was transferred to RO water bath for storage.

The hydrophilicity of the membranes was determined by using contact angle goniometer (Attention Theta Lite).

Table 1. The dope formulation of nano Fe3O4 PVDF/PVP flat sheet membrane.

\begin{tabular}{|l|l|l|l|l|l|}
\hline Membranes & $\begin{array}{l}\text { PVDF } \\
(\mathbf{w t} \%)\end{array}$ & $\begin{array}{l}\text { PVP } \\
(\mathbf{w t} \%)\end{array}$ & $\begin{array}{l}\text { DMF } \\
(\mathbf{w t} \%)\end{array}$ & $\mathbf{F e}_{3} \mathbf{O}_{\mathbf{4}} \mathbf{( w t \% )}$ & Coagulation Bath \\
\hline PVDF 0 & 19 & 3 & 78 & 0 & RO water \\
\hline PVDF 1 & 19 & 3 & 77.9 & 0.1 & RO water \\
\hline
\end{tabular}




\subsection{Characterization of Nano- $\mathrm{Fe}_{3} \mathrm{O}_{4}$}

The chemical composition of the iron oxide nanoparticles was analyzed by using Energy Dispersive X-ray spectroscopy (EDX) Oxford INCA PentaFETX3 (Oxford, UK).

\subsection{Antifouling property of PVDF membranes}

The membrane filtration experiment was conducted by using a $50 \mathrm{ml}$ Millipore dead-end stirrer filtration cell with an effective membrane surface area of $13.4 \mathrm{~cm}^{2}$ (Amicon Stirred cell 50mL). Biological-treated POME obtained from a local mill factory at extended aerobic ponding (Teluk Intan, Perak) was used as the feed. The properties of the feed are shown in Table 2. The filtration cell, which was pressurized by the nitrogen gas, was operated at the transmembrane pressure (TMP) of 1 bar. The membrane was reused for 5 cycles, and it was back washed by using RO water before the next cycle.

The $\mathrm{BOD}_{5}, \mathrm{COD}$ and TSS of the samples were measured to determine the separation performance of the membranes. $\mathrm{BOD}_{5}$ test was conducted according to standard method 5210B. TSS and COD were measured according to photometric method 8006 and APHA standard method 8000 respectively. The solute separation efficiency, $R$ was calculated from Equation (1):-

$$
R=\left(1-\frac{C_{p}}{C_{F}}\right) \times 100 \%
$$

Where $\mathrm{R}$ is rejection efficiency, $\%, \mathrm{C}_{\mathrm{P}}$ is the concentration of permeate, $\mathrm{mg} / \mathrm{L}$, $\mathrm{C}_{\mathrm{F}}$ is the concentration of feed, $\mathrm{mg} / \mathrm{L}$.

Table 2. Characteristic of POME collected from Teluk Intan, Perak

\begin{tabular}{|l|l|}
\hline Properties & Concentration $(\mathrm{mg} / \mathrm{L})$ \\
\hline COD & $2300.73 \pm 136.69$ \\
\hline BOD & $888.52 \pm 194.47$ \\
\hline TSS & $992.00 \pm 40.18$ \\
\hline
\end{tabular}




\section{Results and discussion}

\subsection{Characterization of iron oxide nanoparticles}

The elemental analysis of the synthesized nano- $-\mathrm{Fe}_{3} \mathrm{O}_{4}$ was showed in the EDX spectrum in Figure 1. The atomic percent of $\mathrm{Fe}$ and $\mathrm{O}$ were $25.3 \%$ and $74.7 \%$ respectively. Meanwhile, the weight percentage of $\mathrm{Fe}$ and $\mathrm{O}$ was reported as $54.2 \%$ and $45.8 \%$. The distinctive peak at approximately $0.6 \mathrm{keV}$ due to surface plasmon resonance of the element indicates the presence of $\mathrm{Fe}_{3} \mathrm{O}_{4}$. This is consistent with the finding reported by Zambri et al. (2019), where the $\mathrm{Fe}_{3} \mathrm{O}_{4}$ produced from neem leaf extract showed a peak at approximately $0.6 \mathrm{keV}$ in EDX spectrum. The $\mathrm{x}$-ray diffraction pattern confirmed this result.

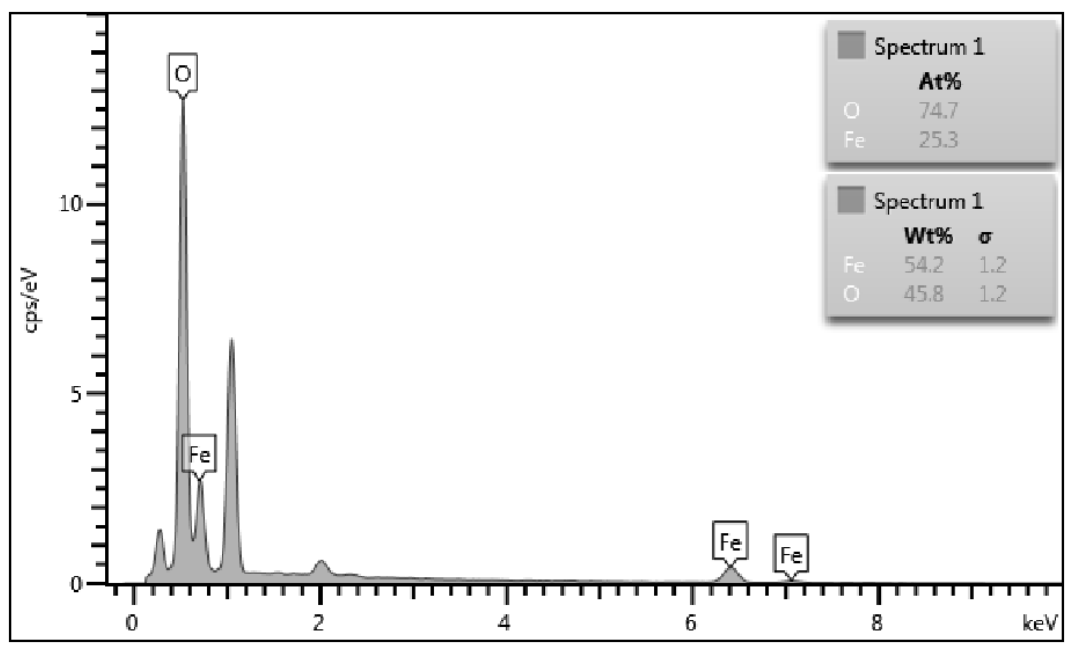

Figure 1. EDX spectrum of nano- $\mathrm{Fe}_{3} \mathrm{O}_{4}$

\subsection{Antifouling performance and reusability studies}

Table 3 showed the hydrophilicity of PVDF membranes and the respective separation performance. The contact angle of PVDF 0 was $77.13 \pm$ $1.58^{\circ}$, which is approximately $7^{\circ}$ higher compared to PVDF 1 membrane. This implies that PVDF 1 was more hydrophilic compared to PVDF 0 due to the presence of nano- $\mathrm{Fe}_{3} \mathrm{O}_{4}$. This is in agreement with the finding reported by Hong and $\mathrm{He}$ (2014) where the presence of $\mathrm{ZnO}$ in PVDF membrane reduced the contact angle of neat PVDF membrane from $70^{\circ}$ to $63^{\circ}$. Similar results 
were also published by Ngang et al. (2017) and Zhang et al. (2015) by using $\mathrm{SiO}_{2}$ and hydroxyapatite, respectively.

Table 3. Separation performance of PVDF 0 and PVDF 1 membranes

\begin{tabular}{|l|l|l|l|l|l|l|l|}
\hline Membrane & Contact & \multicolumn{2}{l|}{ TSS (\%) } & \multicolumn{2}{l|}{ COD $(\%)$} & \multicolumn{2}{l|}{$\mathrm{BOD}_{5}(\%)$} \\
\cline { 3 - 8 } & angle $\left(^{\circ}\right)$ & $\begin{array}{l}1^{\text {st }} \\
\text { cycle }\end{array}$ & $\begin{array}{l}5^{\text {th }} \\
\text { cycle }\end{array}$ & $\begin{array}{l}1^{\text {st }} \\
\text { cycle }\end{array}$ & $\begin{array}{l}5^{\text {th }} \\
\text { cycle }\end{array}$ & $\begin{array}{l}1^{\text {st }} \\
\text { cycle }\end{array}$ & $\begin{array}{l}5^{\text {th }} \\
\text { cycle }\end{array}$ \\
\hline PVDF 0 & $77.13 \pm 1.58$ & 97.82 & 97.88 & 56.45 & 58.38 & 88.67 & 73.15 \\
\hline PVDF 1 & $70.99 \pm 2.72$ & 98.72 & 97.93 & 57.89 & 57.84 & 94.73 & 76.84 \\
\hline
\end{tabular}

Generally, PVDF 1 membrane performed slightly better compared to PVDF 0, especially in BOD removal. PVDF 1 removed $94.73 \%$ of BOD while PVDF 0 removed $88.67 \%$ of BOD in the first cycle. In this cycle, both PVDF membranes successfully treated the BOD up to the discharge limit set by the government, which is 100mg/L (Ahmad et al., 2003; Ma et al., 1993). The final concentration of $\mathrm{BOD}_{5}$ for PVDF 0 and PVDF 1 were $98.22 \mathrm{mg} / \mathrm{L}$ and 45.72 $\mathrm{mg} / \mathrm{L}$, respectively, as showed in Figure 2. This indicates that the presence of nano- $\mathrm{Fe}_{3} \mathrm{O}_{4}$ improved the hydrophilicity of PVDF membrane and thus enhances its performance in removing organic compounds that can be decomposed by microorganism compared to PVDF 0 . The performance of PVDF 1 membrane was better than the composite cellulose membrane produced by Alim et al. (2018), when 70.3\% of BOD5 was removed, and the treated POME showed a BOD concentration of $95 \mathrm{mg} / \mathrm{L}$ in the first cycle.

It is notable that the PVDF membranes exhibited consistent COD ( $\sim 58 \%)$ and TSS ( $\sim 98 \%)$ removal, as showed in Table 3. This results were comparable with the recent work published by Ho et al. (2017), who treated diluted aerobic POME with $151 \mathrm{mg} / \mathrm{L}$ COD and $141.67 \mathrm{mg} / \mathrm{L}$ TSS, 100\% TSS and 75.5\% COD were removed by using graphene oxide/oxidized multi-walled carbon nanotubes mixed-matrix membranes. Although higher rejection rate was achieved by the membrane produced by Ho et al. compared to PVDF 1, the feed concentration used in their study was lower compared to the current study. Besides, the PVDF membranes in study can be reused at least 5 cycles without deleterious the performance. 
Significant reduction in BOD removal was observed in Table 3, where PVDF 1 removed only $76.84 \%$ and PVDF0 removed $73.15 \%$ of BOD in the fifth cycle. Comparatively, the removal performance was $94.73 \%$ and $88.67 \%$ for PVDF 0 and PVDF 1, respectively, in the first cycle. Figure 2 showed an increase in the final concentration of $\mathrm{BOD}_{5}$ from cycle 1 to 5 . It may due to the fouling effect on the membrane surface, and this effect was getting severe as the number of cycle increased. Notably, the highest final BOD reading observed in the $4^{\text {th }}$ cycle may also due to the high BOD concentration in the feed, as showed in Figure 2.

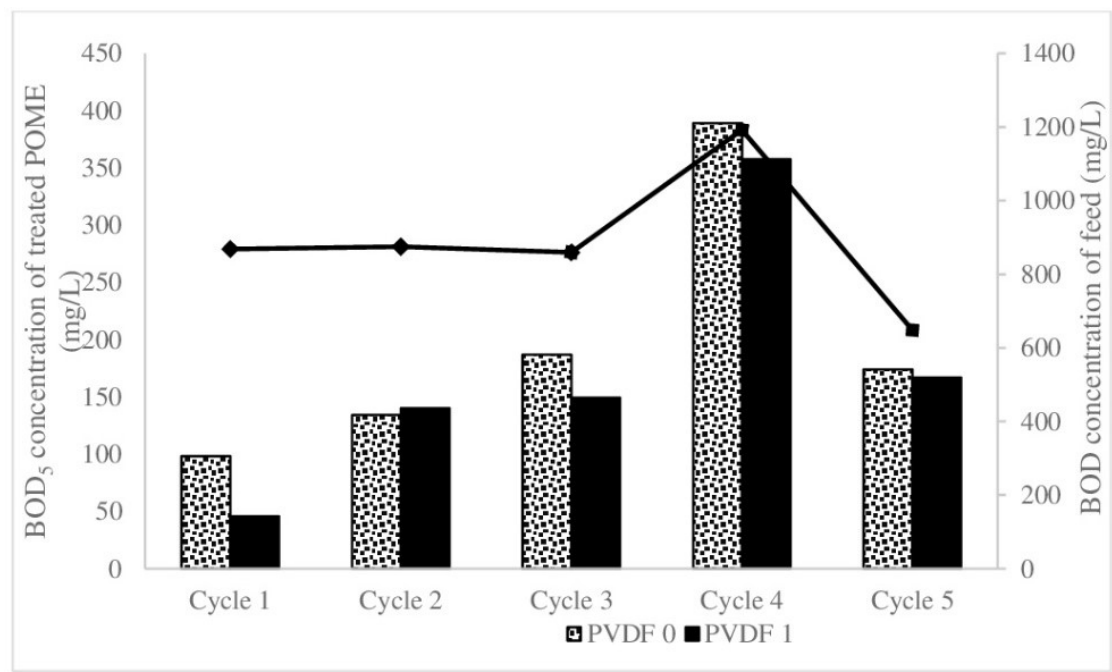

Figure 2. Separation performance of PVDF membranes in terms of BOD.

\subsection{Conclusion}

The present of nano-Fe3O4 improves the antifouling property of PVDF membrane by improving the hydrophilicity of the membrane. Significant improvement was observed in BOD removal where PVDF 1 with nanoFe3O4 removed $94.73 \%$ of BOD5, while the neat membrane showed $88.67 \%$ BOD removal. The membranes also showed consistent TSS and COD removals in the first 5 cycles of recycling the same membranes. The trend of 
reduction in BOD removal rate from the first cycle to the fifth cycle suggested mild fouling phenomenon on the PVDF membrane. It is recommended to improve the RO backwash technique by other cleaning methods such as ultrasound cleaning and chemical cleaning.

\section{Acknowledgement}

The authors would like to thanks Syarikat Peladang Dan Perusahaan Minyak Sdn Bhd, Teluk Intan, Perak for supplying the POME samples and Indah Water Research Centre, Kuala Lumpur for the research facilities. Financial support from SEGi University is also acknowledged.

\section{References}

Ahmad, A. L., Ismail, S., Bhatia, S. (2003). Water recycling from palm oil mill effluent (POME) using membrane technology. Desalination 157: 87 -95 .

Ahmad, A., Bhat, A.H., Buang, A., Shah, S.M.U., and Afzal, M. (2018) 'Biotechnological Application of Microalgae for Integrated Palm Oil Mill Effluent (POME) Remediation: A Review'. International Journal of Environmental Science and Technology

Alim, A. A. A., Othaman, R. (2018). Epoxidized natural rubber/polyvinyl chloride/microcrystalline cellulose (ENR/PVC/MCC) composite membrane for palm oil mill effluent (POME) treatment. Sains Malaysia. 47: 1517 - 1525.

Awotoye, O., Dada, A.C., and Arawomo, G.A.O. (2011) 'Impact of Palm Oil Processing Effluent Discharge on the Quality of Receiving Soil and River in South Western Nigeria'. Journal of Applied Sciences Research, 7 (2), 111-118

Aziz, N.I.H.A. and Hanafiah, M.M. (2017b) 'The Potential Of Palm Oil Mill Effluent (Pome) As A Renewable Energy Source'. Acta Scientifica Malaysia 1 (2), 09-11 
Azmi, N.S. and Yunos, K.F.Md. (2014) 'Wastewater Treatment of Palm Oil Mill Effluent (POME) by Ultrafiltration Membrane Separation Technique Coupled with Adsorption Treatment as Pre-Treatment'. Agriculture and Agricultural Science Procedia 2, 257- 264

Bello, M.M. and Abdul Raman, A.A. (2017) 'Trend and Current Practices of Palm Oil Mill Effluent Polishing: Application of Advanced Oxidation Processes and Their Future Perspectives'. Journal of Environmental Management 198, 170-182

Benavente, J., García, M.E., Urbano, N., López-Romero, J.M., ContrerasCáceres, R.C., Casado-Rodríguez, M.A., Moscoso, A., and Hierrezuelo, J. (2017) 'Inclusion of Silver Nanoparticles for Improving Regenerated Cellulose Membrane Performance and Reduction of Biofouling'. International Journal of Biological Macromolecules 103, 758-763

Chan, M. K. and Teo, H. H. (2013). Semi-Automatic Casting Machine. ID Registration number: MY 13-01324-0101.

Chan, M. K., Preeshaath, R., Yap, K. E., and Joanne, L. M. Y. (2016). A Novel Manufacturing Process to Fabricate Double Layer Membranes. Materials and Manufacturing Processes.31 (15), 1941-1947.

Dalton, O.S., Mohamed, A.F., and Chikere, A.O. (2017) Status Evaluation of Palm Oil Waste Management Sustainability in Malaysia. 9

Ezemonye, L.I.N., Ogeleka, D.F., and Okieimen, F.E. (2008) 'Lethal Toxicity of Industrial Chemicals to Early Life Stages of Tilapia Guineensis'. Journal of Hazardous Materials 157 (1), 64-68

Ghani, M.S.H., Haan, T.Y., Lun, A.W., Mohammad, A.W., Ngteni, R., and Yusof, K.M.M. (2018) 'Fouling Assessment of Tertiary Palm Oil Mill Effluent (POME) Membrane Treatment for Water Reclamation'. Journal of Water Reuse and Desalination 8 (3), 412-423

Guo, J., Guo, P., Yu, M., Sun, Z., Li, P., Yang, T., Liu, J., and Zhang, L. (2018) 'Chemical Reduction of Nitrate Using NanoscaleBimetallic 
Iron/Copper Particles'. Polish Journal of Environmental Studies 27 (5), 2023-2028

He, T., Zhou, W., Bahi, A., Yang, H., and Ko, F. (2014) 'High Permeability of Ultrafiltration Membranes Based on Electrospun PVDF Modified by Nanosized Zeolite Hybrid Membrane Scaffolds under Low Pressure'. Chemical Engineering Journal 252, 327- 336

Ho, K.C., Teow, Y.H., Ang, W.L., and Mohammad, A.W. (2017) 'Novel GO/OMWCNTs Mixed-Matrix Membrane with Enhanced Antifouling Property for Palm Oil Mill Effluent Treatment'. Separation and Purification Technology 177

Homayoonfal, M., Akbari, A., and Mehrnia, M.R. (2010) 'Preparation of Polysulfone Nanofiltration Membranes by UV-Assisted Grafting Polymerization for Water Softening'. Desalination 263 (1-3), 217225

Hong, J. and He, Y. (2014) 'Polyvinylidene Fluoride Ultrafiltration Membrane Blended with Nano-ZnO Particle for Photo-Catalysis Self-Cleaning'. Desalination $332(1), 67-75$

Izah, S.C., Angaye, T.C.N., and Ohimain, E.I. (2016) Environmental Impacts of Oil Palm Processing in Nigeria. 2, 10

Kumar, R. and Ismail, A.F. (2015) 'Fouling Control on Microfiltration/Ultrafiltration Membranes: Effects of Morphology, Hydrophilicity, and Charge'. Journal of Applied Polymer Science 132 (21)

Lalia, B.S., Kochkodan, V., Hashaikeh, R., and Hilal, N. (2013) 'A Review on Membrane Fabrication: Structure, Properties and Performance Relationship'. Desalination 326, 77-95

Ma, A. N., Cheah, S. C., Chow, M. C., Yeoh, B. G. (1993). Current status of palm oil processing wastes management. In: Waste Management in Malaysia: Current status and prospects for bioremediation, Malaysia: Ministry of Science Technology and the Environment. $111-136$. 
MPOB (2008) Summary Of The Malaysian Oil Palm Industry 2008.

MPOB (2014) 'Oil Palm \& The Environment (Updated March 2014)'. The Environment 140

MPOB (2018) Production of Crude Palm Oil 2018.

Ngang, H.P., Ahmad, A.L., Low, S.C., and Ooi, B.S. (2017) 'Preparation of PVDF/SiO2 Composite Membrane for Salty Oil Emulsion Separation: Physicochemical Properties Changes and Its Impact on Fouling Propensity’. IOP Conference Series: Materials Science and Engineering 206, 012083

Ong, C.S., Lau, W.J., Goh, P.S., Ng, B.C., Matsuura, T., and Ismail, A.F. (2014) 'Effect of PVP Molecular Weights on the Properties of PVDFTiO 2 Composite Membrane for Oily Wastewater Treatment Process'. Separation Science and Technology 49 (15), 2303- 2314

Pereira, B. da S., Moreti, L.O.R., Silva, M.F., Bergamasco, R., Piccioli, A. de F.B., Garcia, E.E., Costa, W.V. da, Pineda, E.A.G., Oliveira, D.M.F. de, and Hechenleitner, A.A.W. (2018) 'Water Permeability Increase in Ultrafiltration Cellulose Acetate Membrane Containing Silver Nanoparticles'. Materials Research 20 (suppl 2), 887-891

Yacob, S., Shirai, Y., Hassan, M.A., Wakisaka, M., and Subash, S. (2006) 'Start-up Operation of Semi-Commercial Closed Anaerobic Digester for Palm Oil Mill Effluent Treatment'. Process Biochemistry 41 (4), $962-964$

Zambri, N.D.S., Taib, N.I., Abdul Latif, F., and Mohamed, Z. (2019) 'Utilization of Neem Leaf Extract on Biosynthesis of Iron Oxide Nanoparticles'. Molecules 24 (20), 3803

Zhang, X., Lang, W.-Z., Xu, H.-P., Yan, X., and Guo, Y.-J. (2015) 'The Effects of Hydroxyapatite Nano Whiskers and Its Synergism with Polyvinylpyrrolidone 110 on Poly(Vinylidene Fluoride) Hollow Fiber Ultrafiltration Membranes'. RSC Advances 38 
Zin, M.T., Borja, J., Hinode, H., and Kurniawan, W. (2013) Synthesis of Bimetallic $\mathrm{Fe} / \mathrm{Cu}$ Nanoparticles with Different Copper Loading Ratios. 7 (12), 6 